\title{
Treatment of Acute Lung Injury: Time to Think Outside the Box?
}

\author{
Ryohei Miyata Stephan F. Van Eeden \\ Division of Respirology, Department of Medicine, The University of British Columbia, and The James Hogg \\ Research Center, Providence Heart and Lung Institute, St. Paul's Hospital, Vancouver, B.C., Canada
}

Despite the recent advances in intensive care, acute lung injury (ALI) and acute respiratory distress syndrome are associated with significant morbidity and a persistent high mortality [1]. The reasons for this are multifactorial, one being the diverse etiology or 'triggers' of ALI. These triggers can be divided into 2 broad categories: either direct injury to the lung such as pneumonia and acid aspiration, or indirect injury from systemic sepsis, fat embolism and trauma. The pathogenesis of the acute lung damage is characterized by amplified immune response with overproduction of proinflammatory mediators such as the 'acute response' cytokines, e.g. tumor necrosis factor- $\alpha$ (TNF- $\alpha$ ) and interleukin- $1 \beta$, in response to injurious stimuli. This triggers a cascade of downstream inflammatory pathways that ultimately damage the alveolar epithelial cell and pulmonary vascular endothelial barrier resulting in increased permeability of these 2 barriers causing protein-rich pulmonary edema, neutrophilic inflammation and surfactant dysfunction. The pathogenesis of ALI is complicated and heterogenic due to its multifactorial etiologies, but the functional and pathological endpoints that define the disease are largely similar.

Therefore, the treatment of ALI is inevitably not straightforward and it requires multimodality approach- es including mechanical ventilation, fluid resuscitation and pharmacological therapy with remarkable recent advances in mechanical ventilation (low tidal volume ventilation) [2] and fluid resuscitation (a fluid challenge technique) [3]. Pharmacological therapy includes vasopressors, controlling infection with antibiotics, glucose control, anti-coagulants and anti-inflammatory agents. There has been broad consensus on how to use these pharmacological interventions but for anti-inflammatory agents. This is not due to a lack of interest or effort from the scientific community, because studies involving anti-inflammatory agents have been performed for nearly half a century since corticosteroids were first tested back in 1962 [4]. Since then, numerous studies have been conducted to reduce or neutralize the proinflammatory mediators, including TNF- $\alpha$ and interleukin-1 $\beta$. Despite successful results in animal models, none proved their efficacy in clinical settings. Until now, more than 30 multicenter clinical trials for a variety of anti-inflammatory agents have failed to show any impact on mortality [5]. The failure in clinical settings may reflect delayed treatment. These early cytokines are released within minutes after exposure to pathogens or tissue injury, and even a minimal delay in treatment may result in failure of the cascading inflammatory response. Mice treated with a

\section{KARGER}

Fax +4161306 1234 E-Mail karger@karger.ch www.karger.com
(C) 2010 S. Karger AG, Basel 0025-7931/11/0811-0006\$38.00/0

Accessible online at: www.karger.com/res
Stephan F. Van Eeden

UBC James Hogg Research Center, Providence Heart and Lung Institute

St. Paul's Hospital, Room No. 368A, 1081 Burrard Street

Vancouver, BC V6Z 1 Y6 (Canada)

Tel. +1 604806 8395, Fax +1 604806 9274, E-Mail Stephan.vanEeden@ hli.ubc.ca 
lethal dose of lipopolysaccharide die long after the serum TNF- $\alpha$ level has returned to normal [6], suggesting that 'late-acting mediators' contribute to the development and progression of ALI. Targeting pathways downstream of the 'acute response' to impact the inflammatory response that is driving progressive lung injury may prove to be more realistic and practical. A recent meta-analysis supports this concept, showing the potential beneficial effects of a broad-based nonspecific anti-inflammatory (low-dose steroid treatment) that impact morbidity (including lung injury scores and fibrosis) and possibly mortality [7]. However, randomized controlled studies are lacking, and steroids are currently just a $2 \mathrm{C}$ recommendation (low quality of evidence) in the 2008 International Guidelines of Surviving Sepsis Campaign [8].

Recently, there has been new insight that acetylcholine downregulates inflammation by decreasing proinflammatory cytokines [9]. The anti-inflammatory pathway is mediated by stimulation of the nicotinic acetylcholine receptor, $\mathrm{nAChR}$. More specifically, this effect is mediated by the $\mathrm{nAChR}$ containing the $\alpha 7$ subunit $(\alpha 7 \mathrm{nAChR})$, and stimulation of $\alpha 7 \mathrm{nAChR}$ results in inactivation of the nuclear factor (NF)- $\kappa B$ pathway to suppress the release of proinflammatory cytokines. Nicotine, a prototype nicotinic acetylcholine receptor agonist, inhibits the NF- $\mathrm{B}$ pathway more selectively than acetylcholine. In vivo, nicotine improved survival in septic animal models, even if nicotine was given after the onset of sepsis [10]. The paper by Ni et al. [11] in this issue of Respiration confirmed this sentinel observation, supporting the concept that targeting the 'late-phase' inflammatory response opens up novel options for the management of ALI. They showed reduced lung damage, neutrophil recruitment into the lung, cytokine production and survival even if the nicotine was given $24 \mathrm{~h}$ after the injurious insult.

The beneficial effects of targeting the $\alpha 7 \mathrm{nAChR}$ are predominantly via its effect on the high mobility group box 1 (HMGB1). HMGB1 was initially recognized as a gene transcriptional regulatory factor, but was recently identified as a late mediator for ALI since serum levels increase 20-72 h after onset [12]. The role of HMGB1 in the pathogenesis of ALI appears to be clearly distinct from other earlier expressing cytokines. HMGB1 production is suppressed by stimulation of $\alpha 7 \mathrm{nAChR}$. Several recent studies have reported beneficial therapeutic effects of targeting HMGB1 (neutralizing with anti-HMGB1 antibodies or stimulating $\mathrm{nAChR}$ ) on both survival and histological severity of ALI [13]. This 'late-mediator targeting therapy' may provide a broader time frame for pharmacological intervention. All the studies targeting HMGB1 use animal models, and clearly, human studies are needed. Furthermore, targeting one specific mediator has a limited beneficial effect (in humans) on the complex inflammatory milieu of ALI as numerous previous studies have shown. Therefore, it is an attractive option to target a key step in the inflammatory cascade such as NF$\kappa \mathrm{B}$ activity via the $\alpha 7 \mathrm{nAChR}$.

There are potential downsides to targeting such a key step in the inflammatory cascade. Most triggers for ALI stimulate an innate immune response (recognition via Toll-like receptors) to activate the NF- $\kappa \mathrm{B}$ pathway to produce proinflammatory cytokines. This cascade of events is essential to initiate the adaptive immune response, pivotal to protect against infectious organisms. In bacterial peritonitis-induced ALI, nicotine increased lung neutrophil infiltration and mortality because of impaired bacterial clearance [14]. Nicotine suppresses microbicidal activity, antigen-presenting cell responses, T-cell-dependent antibody production and skews the macrophage 1 phenotype to the more innate immune macrophage 2 phenotype [15]. Furthermore, MyD88deficient mice show a profound defect in the activation of antigen-specific T-helper type 1 [16] illustrating the potential downside of damping the innate immune response. Therefore, an ideal therapeutic agent for ALI should downregulate an overactive innate immunity and preserve or upregulate adaptive immunity. However, the conditions determining the interaction between innate and adaptive immunity are complex and largely unknown. Therefore, the best strategy is to dampen NF$\kappa \mathrm{B}$ activity to reduce proinflammatory cytokine production and release with adequate antibiotherapy to compensate for the impaired adaptive immunity functions. Lastly, in humans, the use of nicotine to target HMGB1 (and ultimately NF- $\kappa \mathrm{B}$ ) is limited due to its potential systemic toxicity on the cardiovascular, neurological and coagulation systems. The use of selective $\alpha 7 \mathrm{nAChR}$ agonists can solve these disadvantages, and a selective $\alpha 7 n A C h R$ agonist (GTS-21) has already been used in clinical trials for Alzheimer disease.

A key issue is whether the inciting trigger for ALI determines the response to blocking $\alpha 7 \mathrm{nAChR}$, highlighted by the contrasting results from the instilling lipopolysaccharide in the lung $[10,11]$ to ALI induced by the systemic effects of the remote infection [14]. In general, ALI induced by triggers such as trauma and acid aspiration has better outcomes than ALI triggered by systemic infection or sepsis. Together, it suggests that the etiology of ALI may be pivotal in the decision whether to block $\alpha 7 \mathrm{nAChR}$ 
as an anti-inflammatory strategy. Defining the actual pathophysiological phenotype in each subject may be the future to target anti-inflammatory therapy in ALI. Clearly, it does not seem to be realistic to treat ALI targeting a single inflammatory mediator, and recent studies suggest that targeting anti-inflammatory therapy to the 'latephase inflammatory response' is a new and promising option.

\section{References}

1 Rubenfeld GD, Caldwell E, Peabody E, Weaver J, Martin DP, Neff M, Stern EJ, Hudson LD: Incidence and outcomes of acute lung injury. N Engl J Med 2005;353:16851693.

-2 Amato MB, Barbas CS, Medeiros DM, Magaldi RB, Schettino GP, Lorenzi-Filho G, Kairalla RA, Deheinzelin D, Munoz C, Oliveira R, Takagaki TY, Carvalho CR: Effect of a protective-ventilation strategy on mortality in the acute respiratory distress syndrome. N Engl J Med 1998;338:347-354.

$\checkmark 3$ Bendjelid K, Romand JA: Fluid responsiveness in mechanically ventilated patients: a review of indices used in intensive care. Intensive Care Med 2003;29:352-360.

4 Bennett IL Jr, Finland M, Hamburger M, Kass EH, Lepper M, Waisbren BA: A doubleblind study of the effectiveness of cortisol in the management of severe infections. Trans Assoc Am Physicians 1962;75:198-207.

$\checkmark 5$ Ulloa L, Tracey KJ: The 'cytokine profile’: a code for sepsis. Trends Mol Med 2005;11:56 63.

6 Marino MW, Dunn A, Grail D, Inglese M, Noguchi Y, Richards E, Jungbluth A, Wada H, Moore M, Williamson B, Basu S, Old LJ: Characterization of tumor necrosis factordeficient mice. Proc Natl Acad Sci USA 1997; 94:8093-8098.
7 Tang BM, Craig JC, Eslick GD, Seppelt I, McLean AS: Use of corticosteroids in acute lung injury and acute respiratory distress syndrome: a systematic review and metaanalysis. Crit Care Med 2009;37:1594-1603.

8 Dellinger RP, Levy MM, Carlet JM, Bion J, Parker MM, Jaeschke R, Reinhart K, Angus DC, Brun-Buisson C, Beale R, Calandra T, Dhainaut JF, Gerlach H, Harvey M, Marini JJ, Marshall J, Ranieri M, Ramsay G, Sevransky J, Thompson BT, Townsend S, Vender JS, Zimmerman JL, Vincent JL: Surviving Sepsis Campaign: international guidelines for management of severe sepsis and septic shock: 2008. Crit Care Med 2008;36:296327.

9 Borovikova LV, Ivanova S, Zhang M, Yang H, Botchkina GI, Watkins LR, Wang H, Abum$\operatorname{rad} \mathrm{N}$, Eaton JW, Tracey KJ: Vagus nerve stimulation attenuates the systemic inflammatory response to endotoxin. Nature 2000; 405:458-462.

10 Wang $H$, Liao H, Ochani M, Justiniani M, Lin X, Yang L, Al-Abed Y, Metz C, Miller EJ, Tracey KJ, Ulloa L: Cholinergic agonists inhibit HMGB1 release and improve survival in experimental sepsis. Nat Med 2004;10: 1216-1221.

11 Ni YF, Tian F, Lu ZF, Yang GD, Fu HY, Wang J, Yan XL, Zhao YC, Wang YJ, Jiang T: Protective effect of nicotine on lipopolysaccharide-induced acute lung injury in mice. Respiration 2011;81:39-46.
12 Wang $\mathrm{H}$, Bloom O, Zhang M, Vishnubhakat JM, Ombrellino M, Che J, Frazier A, Yang H, Ivanova S, Borovikova L, Manogue KR, Faist E, Abraham E, Andersson J, Andersson U, Molina PE, Abumrad NN, Sama A, Tracey KJ: HMG-1 as a late mediator of endotoxin lethality in mice. Science 1999;285:248-251.

13 Yang H, Ochani M, Li J, Qiang X, Tanovic M, Harris HE, Susarla SM, Ulloa L, Wang H, DiRaimo R, Czura CJ, Roth J, Warren HS, Fink MP, Fenton MJ, Andersson U, Tracey KJ: Reversing established sepsis with antagonists of endogenous high-mobility group box 1 . Proc Natl Acad Sci USA 2004;101:296-301.

14 Boland C, Collet V, Laterre E, Lecuivre C, Wittebole $\mathrm{X}$, Laterre PF: Electrical vagus nerve stimulation and nicotine effects in peritonitis-induced acute lung injury in rats. Inflammation DOI: 10.1007/s10753-0109204-5.

15 Nouri-Shirazi M, Guinet E: Evidence for the immunosuppressive role of nicotine on human dendritic cell functions. Immunology 2003;109:365-373.

16 Schnare M, Barton GM, Holt AC, Takeda K, Akira S, Medzhitov R: Toll-like receptors control activation of adaptive immune responses. Nat Immunol 2001;2:947-950. 